\author{
Natalia Szomko \\ Ph.D. Student, Capital Markets Department, \\ Warsaw School of Economics, Poland
}

\title{
Investor Reaction to Information on Final Dividend Payouts on the Warsaw Stock Exchange - an Event Study Analysis
}

\begin{abstract}
This article analyzes the investor reaction to information on the final value of dividend payouts for companies listed on the Warsaw Stock Exchange, using the event study methodology. Our research shows that investor reaction is positive for irregular payouts and both the initiation of and the increase in payouts, while negative for the resumption and of and decreases in payouts. The magnitude of the reaction is also higher for the initiation of payouts than either the increases in, or irregular payouts.

This study contributes to the literature on dividend policy by presenting results for the emerging economy of Poland. Moreover, it pays particular attention to statistical issues related to the event study methodology, i.e., the verification of assumptions behind the method of returns model estimation. It also compares investor reaction to dividend changes assessed on the basis of different measures, and underlines the dependence of the results on the choice of the parameters assumed (e.g., event window length).
\end{abstract}

Keywords: information and market efficiency, dividend, payout policy, investors' reaction JEL: G14, G35 


\section{Introduction}

This paper analyzes investor reaction to dividend policy changes for companies listed on the Warsaw Stock Exchange (WSE), as an event study. We find that investor reaction to irregular payout, payout initiation and increases in payouts is positive. By contrast, they are negative when payouts are resumed or decreased. At the same time, the highest magnitude of positive reaction is observed for payout initiation.

The study adds to existing research by undertaking a detailed analysis of the statistical issues related to use of the market model in event studies, i.e., verification of ordinary least squares assumptions. Not only does the magnitude change depending on the assumed significance level, but also the direction of investor reaction. Moreover, the results differ if changes in dividend policy are analyzed with different metrics (change in nominal value, dividend yield, and dividend payout yield). The issues in question have not been commented on in previous studies.

There are five dominant views on the impact of dividend policy on the value of a company: "a bird in the hand" fallacy; the dividend irrelevance proposition; the signalling hypothesis; the agency cost hypothesis; and the clientele effect (cf. Kalay and Lemmon [2008]).

"A bird in the hand" fallacy claims that investors faced with uncertainty have a strict preference for capital gains combined with dividend income. According to Gordon [1959, 1963], uncertainty about future growth of share values and possible share issuance investors might cause investors to value 5 USD in dividends and 50 USD in capital gains more than 55 USD in capital gains alone. Therefore, the value of a company's shares should equal the sum of discounted dividends from now to infinity.

The dividend irrelevance proposition was formulated by Miller and Modigliani [1961]. In a perfect economy, the rate of return obtained from every company's share is equal in a specified time period. In the long run, the share price depends only on the profitability of the company. Lintner [1962] continues the analysis, including transaction costs and differences in taxation rates, to claim that investors always prefer financing investments with retained earnings. Therefore no dividends should be paid.

According to the signalling hypothesis, shareholders view increased dividend payouts as a positive change in managers' opinions of the future prospects of the company [Levinsohn, 2005]. Due to the fact that earnings forecasts are not communicated because of high volatility [Woolridge, 1983], managers prefer to use dividends as a tool for conveying their opinion. Jagannathan et al. [2000] underline that this signal is credible as long as regular payouts are altered. The signalling hypothesis is described formally in Bhattacharya [1979], John and Wiliams [1985], Bernheim [1991] and Lucas and McDonald [1998].

The agency cost hypothesis stipulates that managers are imperfect agents of the principal, i.e., shareholders (Jensen [1986]). Apart from increasing the company's value, agents 
might pursue their personal goals by creating additional costs and forcing shareholders to undertake costly monitoring of managers. As Rozeff [1982] states, establishing a regular dividend payout is one measure to diminish free cash flow available to managers. The issue is further examined by Easterbrook [1984], Jensen [1986] and La Porta et al. [2000].

The clientele effect hypothesis raises the issue of different dividend preferences. Companies attract investors who value their payout policy. Elton and Gruber [1970] state that changes in a company's clientele, combined with transaction costs, create short-term, unfavourable price movements. Michaely, Thaler and Womack [1995] suggest two motives influencing dividend preference: economic and psychological. Investor preferences are further examined by Brennan and Thakor [1990], Allen et al. [2000] and Baker and Wurgler [2004].

Empirical research concerning investors' reaction to dividend payouts is ample. Litner [1956] and Brav et al. [2003] present managers' view, concluding that they are reluctant to decrease payouts. Positive (negative) reaction to dividend increases (decreases) was observed by most of the studies, including Denis et al. [1994], Pettit [1972], Aharony and Swary [1980], Woolridge [1983], Capstaff et al. [2004], Amihud and Li [2006] Fracassi [2008]. Litzenberger and Ramaswamy [1982], Michaely et al. [1995], Kane et al. [1984], Asquith and Mullins [1983], Ghosh and Woolridge [1989], DeAngelo et al. [1992], Jensen and Johnson [1995] and Robin [1998]. Furthermore, the reliability of the dividend signal was analyzed by Yoon and Starks [1995], Nissim and Ziv [2001], Miklahil et al. [1999], Gelb [2000], La Porta et al. [2000] and Chang et al. [2006]. However, several researchers noticed the lack of a signalling effect (Bernartzi et al. [1997], Grullon et al. [2003], Vieira and Raposo [2003], Goddard et al. [2006], Li and Zhao [2008], and Jo and Pan [2009]). This issue was considered by Gurgul and Majdosz [2005], Perepeczo [2013], Czerwonka [2010] and Słoński and Zawadzki [2012], using empirical research for the Polish market.

To conclude, the signalling hypothesis is examined by most studies on investor reaction to dividend payouts. Many studies confirm significant investor reaction to dividend changes, initiations and omissions. Ambiguity of the results, and their magnitude, can be partly explained by differences in study design.

\section{Hypotheses}

According to both the signalling and agency cost hypotheses, dividends are viewed as positive information by investors. Therefore, higher than expected payouts should elicit positive investor reaction, and lower payouts should cause a negative investor reaction.

In the research presented in this paper, the investor reaction to the event is assessed in relation to the following events: 
- irregular payouts, i.e., payouts made by a company that did not pay dividends 2 years before and after the event, ${ }^{1}$

- payout initiation, i.e., payouts made by a company that did not pay dividends 2 years before the event but, after initiation, continued dividend payments in the next or the following year (1 year of omission is accepted),

- payout resumption, i.e., payouts made by a company that paid dividends after 1 year of omission,

- payout continuation, i.e., payouts made by a company that are diminishing, unchanged, or increasing.

Based on the results of previous studies, as well as the signalling and agency cost hypotheses stipulations, the following hypotheses are formulated:

Main hypothesis: Investor reaction to information about irregular payouts, payout initiation, payout resumption, and increasing payouts is positive, while reaction to information about diminishing payouts is negative.

\section{Additional hypotheses:}

1) The magnitude of positive investor reaction is the highest in the case of payout initiation, and the lowest in the case of irregular payments.

2) Investor reaction to increased dividend payments is smaller, relative to payout initiation announcements.

3) Investor reaction to information that there is no change in dividend payments is small, relative to investor reaction to dividend change announcements.

The additional hypotheses listed above are in line with most empirical studies. As noted by Kane et al. [1994], the more positive the announcements, the higher the magnitude of investor reaction. Stronger reaction to payout initiation was also posited by Asquith and Mullins [1983], while significant investor reaction to increases and decreases in dividend payments was observed by Pettit [1972], Aharony and Swary [1980], Woolridge [1983], Denis et al. [1994], Capstaff et al. [2004], Amihud and Li [2006], and Fracassi [2008].

\section{Study Design and Data}

The focus of the study is to assess investor reactions to changes in dividend payouts for companies listed on the WSE. Data on dividend payouts come from GPW Info Strefa [www.gpwinfostrefa.pl]. From 1997 to the end of 2010, 816 payments are identified. Data concerning General Shareholders' Meeting dates and payout values are complemented by financial statement data obtained from the Notoria Database. Share prices are generated from Bloomberg.

The study is based on the event analysis methodology introduced by Fama et al. [1969], and described in detail by, e.g., Gurgul [2012] and Campbell et al. [1997]. The main steps of the event study are: event identification, selecting time parameters of the 
study, establishing the relationship between rate of return for the company and market index return, and estimating the effect of the event using sample data.

For this research voting on the dividend payout at a General Shareholders' Meeting ("GSM") is defined as an event. Since events should not be anticipated by market players, these chosen dates have only partial credibility. However, earlier declarations of management are also often imprecise. Additionally, GSMs usually involve discussion of company results for the previous period, and the two effects might be impossible to separate. The GSM date is the first day when information concerning the final value of dividend payout is available.

On the basis of the empirical research presented above, the chosen time parameter is a 124-day estimation window is chosen, i.e., from the 125 th day to the 1 st day before the GSM. The event window is from the 1 st day before to the 1 st day after the GSM (days -1, $0,1)$.

Because the assumption underlying the event analysis determines the validity of the model's description of the relationship between security and market rate of return, it is critically importance to select the best model. According to Campbell, Lo and MacKinlay [1997], the use of multifactor models - in comparison with the market model - results in only a small added value. Since the market model is also the prevailing method used in previous research [Gurgul, 2012, p. 43], it is used in this study, too.

The market model is estimated with ordinary least squares method (OLS). However, it has to be stressed that the model is appropriate for forecasting only if the OLS assumptions are fulfilled. To assure the model's validity, the properties of the models for each event were examined by Shapiro-Wilk's normality test (null hypothesis: normally distributed errors), Breusch-Godfrey's autocorrelation test up to the fourth order (null hypothesis: no serial correlation of errors), and White's heteroscedasticity test (null hypothesis: homoscedasticity of errors). Three distinctive significance levels were used: 0.1, 0.05 and 0.01.

Abnormal returns are calculated as residuals from the market model: ${ }^{2}$

$$
A R_{i t}=R_{i t}-E\left(R_{i t}\right)=R_{i t}-\alpha-\beta \times R_{m t}
$$

where $R_{i t}$ stands for the logarithmic rate of return for company $i$ in period $t$, while $E\left(R_{i t}\right)$ is the expected rate of return calculated on the basis of the market model. $R_{m t}$ is the logarithmic rate of return for the market. To obtain cumulative abnormal returns (CAR), abnormal returns (AR) are averaged across the events and added across time in the event window:

$$
C A R=\frac{1}{N} \sum_{t=t_{0}}^{t_{0}+T-1} \sum_{i=1}^{N} A R_{i t}
$$

where $\mathrm{N}$ is the number of events analyzed, $\mathrm{T}$ is the length of the event window, while $\mathrm{t}_{0}$ is the first day of the event window. In order to assess the significance of the results, standard deviation of average abnormal returns is calculated according to the formula: 


$$
\widehat{\sigma}_{\overline{A R_{t}}}=\sqrt{\frac{1}{T-1} \sum_{t=t_{0}}^{t_{0}+T-1}\left(\overline{A R_{t}}-\overline{\overline{A R}}\right)^{2}}
$$

where $\overline{A R}$ is mean abnormal return averaged by events, while $\overline{\overline{A R}}$ is the mean abnormal return averaged by events and days in the estimation window.

The significance of CARs is tested with t-statistics with $\mathrm{N}-1$ degrees of freedom:

$$
t_{\text {stat }}=\frac{C A R}{{\hat{\sigma} \overline{A R_{t}}}_{t}} \sqrt{N}
$$

Investor reaction to the event is assessed for irregular payouts, payout initiation, payout resumption, and payout continuation (for the definition of events, see p. 6).

The change in dividend payout may be assessed on the basis of different measures [Hawton, Hawton, 2006, p. 64]. The simplest is the absolute value of dividend per share. The second measure is dividend yield, i.e., the dividend per share divided by the share price, which can be measured at the end of the fiscal year, at the beginning of the fiscal year adjusted to the market index change, or on the day of the GSM. The last measure is the dividend payout yield, i.e., the fraction of company earnings distributed to shareholders. The choice among those five measures can be made only subjectively. Therefore, all of them are presented in the analysis.

To sum up, the significance of abnormal returns is verified against the full sample and against companies with OLS assumptions fulfilled at one of three significance levels (as the choice of significance level is subjective). Notably, previous research does not test market model validity. Four groups of events are defined, with three sub-groups distinguished among the continuing payout based on five criteria.

\section{Irregular Payouts}

This section describes investor reaction to irregular payouts, i.e., when the company did not pay dividends 2 years before and after the event. In table 2 CARs are presented for different length of event windows and significance levels used for the testing of OLS assumptions.

CARs for irregular payouts are positive in 9 out of 20 cases presented in the table above. When restricting the analysis to significant investor reaction, in 5 out of 6 cases the reaction is positive.

Taking into consideration the whole event window, i.e., days $-1,0$ and 1, CARs are significantly different from zero only when the 0.1 significance level is applied. In that case, the abnormal return amounts to $1.73 \%$. Also for a 2-day event window, excluding the day before the event, CARs when the OLS assumptions are fulfilled at a 0.1 significance level 
are significantly different from zero, and equal 1.54\%. For 0.05 significance level, 2-days CARs are also positive and significant, though smaller in magnitude.

TABLE 2. CARs for irregular dividend payments vs. OLS assumptions

\begin{tabular}{|c|c|c|c|c|c|c|}
\hline & \multicolumn{6}{|c|}{ OLS assumptions fulfilled at the significance level } \\
\hline & \multicolumn{2}{|c|}{0.1} & \multicolumn{2}{|c|}{0.05} & 0.01 & all events \\
\hline number of events & \multicolumn{2}{|c|}{11} & \multicolumn{2}{|c|}{17} & 27 & 86 \\
\hline CARs in days- $1,0,1$ & $1.73 \%$ & $* * *$ & $0.31 \%$ & & $-0.56 \% \quad \star *$ & $-0.74 \%$ \\
\hline CARs in days 0,1 & $1.54 \%$ & $* * *$ & $0.52 \%$ & $* *$ & $-0.16 \%$ & $-0.31 \%$ \\
\hline CARs in day- 1 & $0.19 \%$ & & $-0.21 \%$ & & $-0.40 \%$ & $-0.43 \%$ \\
\hline CARs in day0 & $0.23 \%$ & & $-0.24 \%$ & & $-0.31 \%$ & $-0.04 \%$ \\
\hline CARs in day1 & $1.32 \%$ & $* * *$ & $0.76 \%$ & ** & $0.15 \%$ & $-0.27 \%$ \\
\hline
\end{tabular}

* significant at the 0.1 level; ${ }^{* *}$ significant at the 0.05 level; ${ }^{* * *}$ significant at the 0.01 level.

S o u r c e : own elaboration on the basis of SAS System outcome.

Difference in the magnitudes and significance of CARs for different event windows can be explained by observing results for the three days separately. Not only are CARs for day -1 insignificant regardless of OLS assumption fulfilment, but also for day 0 . As a consequence, the significance of investor reaction to irregular dividend payments results from positive CARs gained on the day following GSM, i.e., day 1. In 17 events, returns for which the market model is properly specified at the 0.05 significance level reveal abnormal returns on day 1 amount to $0.76 \%$, while for the 11 events chosen at the 0.1 significance level the abnormal return stands at $1.32 \%$.

It is also worth mentioning that if the OLS assumptions are unfulfilled or a 0.01 significance level is chosen, CARs for separate days are insignificant in these subgroups of events. Moreover, all but one are negative - positive CARs are observed only for day 1 and significance level 0.01 .

Taking all of the above into account investor reaction to irregular payouts can be described as moderately positive.

\section{Payout Initiation}

From the time perspective, assessment of payout initiation as the event is simplified. However, because declarations of future payments are inherently uncertain, the initiation event is defined as a payout that is continued in the next, or following year ( 1 year of omission is accepted). The CARs are presented in the table 3. 
TABLE 3. CARs for payout initiation vs. OLS assumptions

\begin{tabular}{|l|l|l|c|c|c|c|c|}
\cline { 2 - 7 } \multicolumn{1}{c|}{} & \multicolumn{5}{c|}{ OLS assumptions fulfilled at the significance level } \\
\cline { 2 - 8 } \multicolumn{1}{c|}{} & \multicolumn{2}{c|}{0.1} & \multicolumn{2}{c|}{0.05} & \multicolumn{2}{c|}{0.01} & all events \\
\hline number of events & \multicolumn{2}{c|}{32} & \multicolumn{2}{c|}{51} & \multicolumn{2}{c|}{72} & 159 \\
\hline CARs in days-1, 0, 1 & $2.44 \%$ & $* * *$ & $0.09 \%$ & & $0.21 \%$ & $-0.38 \%$ \\
\hline CARs in days0, 1 & $1.37 \%$ & $* * *$ & $-0.42 \%$ & $*$ & $-0.16 \%$ & & $-0.19 \%$ \\
\hline CARs in day-1 & $1.06 \%$ & $* * *$ & $0.52 \%$ & $* *$ & $0.37 \%$ & & $-0.19 \%$ \\
\hline CARs in day0 & $0.96 \%$ & $* * *$ & $0.74 \% \quad * * *$ & $0.67 \% \quad * * *$ & $0.29 \%$ \\
\hline CARs in day1 & $0.42 \%$ & $*$ & $-1.16 \% \quad * * *$ & $-0.83 \% \quad * * *$ & $-0.48 \%$ \\
\hline
\end{tabular}

${ }^{*}$ significant at the 0.1 level; ${ }^{* *}$ significant at the 0.05 level; ${ }^{* * *}$ significant at the 0.01 level.

S o u r c e : own elaboration on the basis of SAS System outcome.

To begin with, 12 CARs out of 20 defined in the above table are positive. When restricting the analysis to significant investor reaction, in 8 cases out of 11 the reaction is positive.

For 32 events where market model assumptions are fulfilled at the 0.1 significance level, not only are CARs for 3-day and 2-day event periods positive and significantly different from zero, but so are CARs for individual days. Therefore, it can be said that within days -1 to 1 around the GSM, CARs stand at $2.44 \%$, while for days 0 to 1 the return in question amounts to $1.37 \%$.

With OLS assumptions fulfilled at the 0.05 level, both 2-days and 3-days CARs are not significantly different from zero, mainly due to the negative CARs observed in day 1 , i.e., after the announcement of a dividend payout. Moreover, as with irregular payouts, the reaction to payout initiation is assessed when OLS assumptions are unfulfilled or fulfilled at 0.01 level is insignificantly different from zero for all periods listed in the table 3 .

To conclude, investor reaction to payout initiation can be viewed as positive.

\section{Payout Resumption}

As the history of the WSE is short relative to American stock exchanges, the popularity of stable dividend policies in Poland is also much lower. Therefore, to extend the sample of continuing payouts, a fourth category of event is established, i.e., payout resumption. The results of the analysis for these events are presented in table 4.

CARs for payout resumption are positive in 2 out of 20 cases defined in the table above. When restricting the analysis to significant investor reaction, in only 1 out of 17 cases was the reaction positive.

For the event of payout resumption, regardless of the fulfilment of OLS assumptions CARs for 3-days and 2-days event window are significantly negative and vary between $-1.82 \%$ for days $-1,0$ and 1 and 0.05 significance level, to $-0.51 \%$ for the whole sample 
and 3-days event window. The only case when positive significant CARs are observed is on day -1 for the event when the OLS assumptions are fulfilled at a 0.1 level.

To sum up, investor reaction to resuming dividend payouts is negative.

\section{TABLE 4. CARs for payouts resumption vs. OLS assumptions}

\begin{tabular}{|l|c|l|c|c|c|l|l|l|}
\cline { 2 - 9 } \multicolumn{1}{c|}{} & \multicolumn{5}{c|}{ OLS assumptions fulfilled at the significance level } \\
\cline { 2 - 9 } \multicolumn{1}{c|}{} & \multicolumn{2}{c|}{0.1} & \multicolumn{2}{c|}{0.05} & \multicolumn{2}{c|}{0.01} & \multicolumn{2}{c|}{ all events } \\
\hline number of events & \multicolumn{2}{c|}{12} & \multicolumn{2}{c|}{15} & \multicolumn{2}{c|}{52} \\
\hline CARs in days-1, 0,1 & $-1.32 \%$ & $* * *$ & $-1.82 \%$ & $* * *$ & $-1.84 \%$ & $* * *$ & $-0.51 \%$ & $* *$ \\
\hline CARs in days0, 1 & $-1.63 \%$ & $* * *$ & $-1.75 \%$ & $* * *$ & $-1.15 \%$ & $* * *$ & $-0.61 \%$ & $* *$ \\
\hline CARs in day-1 & $0.31 \%$ & $*$ & $-0.08 \%$ & & $-0.68 \%$ & $* * *$ & $0.10 \%$ & \\
\hline CARs in day0 & $-1.18 \%$ & $* * *$ & $-0.84 \%$ & $* * *$ & $-0.64 \%$ & $* * *$ & $-0.04 \%$ & \\
\hline CARs in day1 & $-0.44 \%$ & $* *$ & $-0.90 \%$ & $* * *$ & $-0.52 \%$ & $* * *$ & $-0.57 \%$ & $* *$ \\
\hline
\end{tabular}

${ }^{*}$ significant at the 0.1 level; ${ }^{* *}$ significant at the 0.05 level; ${ }^{* * *}$ significant at the 0.01 level.

S o u r c e: own elaboration on the basis of SAS System outcome.

\section{Payout Continuation}

According to the design of the study described above, investor reaction to payout continuation is assessed on the basis of different criteria for distinguishing the direction of change in dividend payment. CARs for 2-days and 3-days event windows vs. OLS assumptions, taking into account the first criterion, i.e., the percentage change in dividend payout, are presented in table 5. The results tabulated in this section do not include CARs for single days of the event window to preserve transparency regarding analysis outcomes.

CARs for a decrease in dividend payouts are negative in 1 out of 8 cases defined in the table above. For this event, CARs were significantly different from zero only at the 0.05 significance level. However, the values in question are positive, amounting to $1.74 \%$ for days $-1,0,1$ and $1.08 \%$ for days 0 and 1 . CARs for unchanged dividend payouts are negative in 8 out of 8 cases defined. In order for them to be significantly different from zero, the market model would have to be properly specified at the $0.01,0.5$ or 0.1 level. The magnitude of 3 -days CARs varies from $-1.79 \%$ to $-1.05 \%$, while for 2 days CARs it lies between $-1.62 \%$ and $-1.05 \%$.

CARs for an increase in dividend payouts are positive in 1 out of 8 cases defined in the table above. Investors react mostly negatively to the information concerning increases in dividend payouts, and cumulative abnormal returns are significant when the 0.01 or 
0.05 significance level is chosen. For 3-days event windows, the reaction lies between $-0.77 \%$ and $-0.52 \%$, while for 2 -days event window it is between $-0.79 \%$ and $-0.49 \%$.

TABLE 5. CARs for payout continuation - decrease, no change and increase in percentage change in payout vs. OLS assumptions

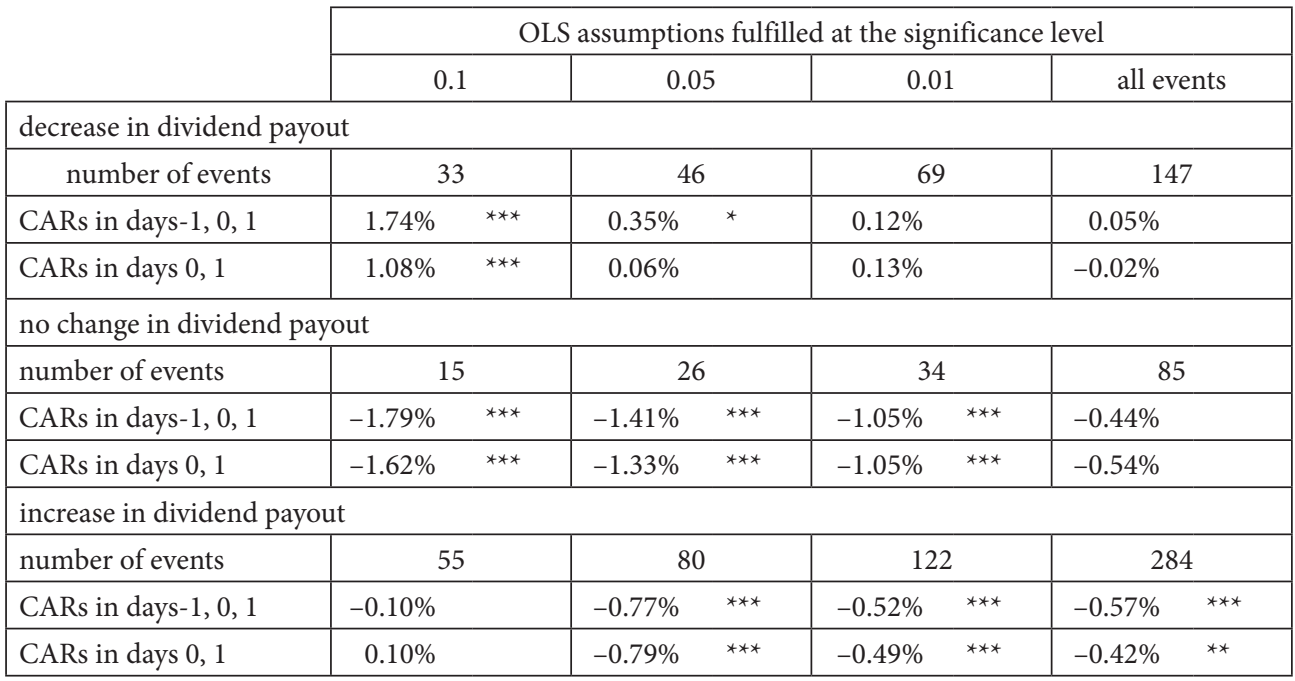

* significant at the 0.1 level; ${ }^{* *}$ significant at the 0.05 level; ${ }^{* * *}$ significant at the 0.01 level.

S o u r c e : own elaboration on the basis of SAS System outcome.

Taking all of the above into account, when the direction of dividend change is assessed as a percentage change in payment value, the observed reaction is positive for diminishing payouts and negative for no change or an increase in payouts.

Another criterion for grouping events of continuing dividend payouts is the change in dividend rate based on the share price on the day of GSM. The CARs for these events are presented in table 6 .

CARs for decreased dividend rates are negative in 8 out of 8 cases presented in the table above, while in case of increases they are positive in 2 out of 8 cases.

In case of decreases in the dividend rate, if OLS assumptions are fulfilled at the 0.05 or 0.1 level, CARs are significantly different from zero, ranging from $-0,77 \%$ to $-0.56 \%$ for 3 -days event window and from $-0.58 \%$ to $-0.48 \%$ for 2 -days event window. Secondly, there are no events if the dividend rate does not change. Regarding increased dividend rates, CARs for 2-days and 3-days event window are positive and significant at the significance level of 0.1 ( $0.62 \%$ and $0.82 \%$, respectively). Contrary to this finding, CARs for days 0,1 are negative and significant when the level of significance for OLS assumptions is 0.05 or 0.01 . 
TABLE 6. CARs for payout continuation - decrease and increase in change in the dividend rate based on the share price on the day of GSM vs. OLS assumptions

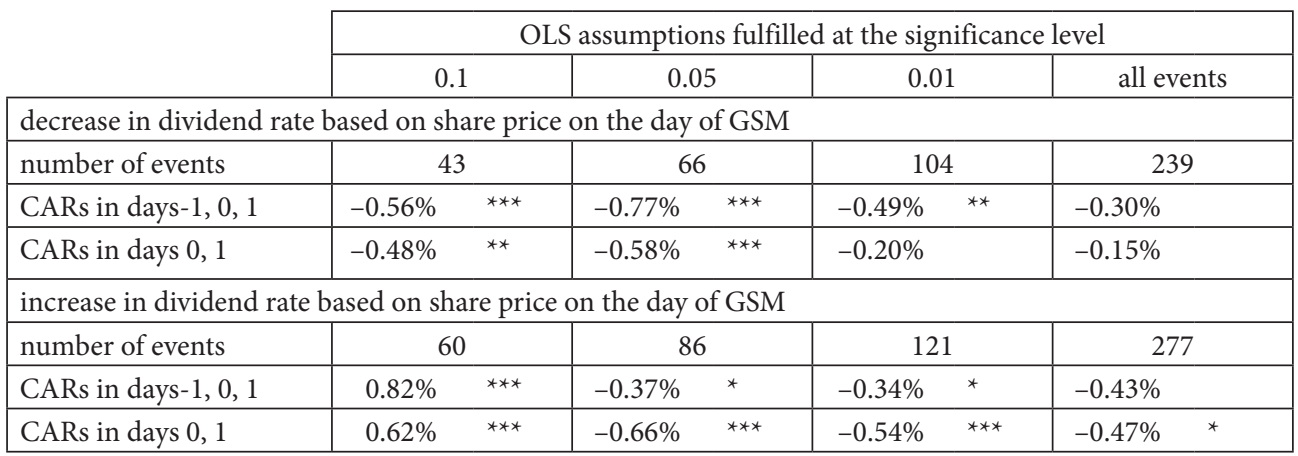

${ }^{*}$ significant at the 0.1 level; ${ }^{* *}$ significant at the 0.05 level; ${ }^{* *}$ significant at the 0.01 level.

S o u r c e: own elaboration on the basis of SAS System outcome.

To sum up, classifying events of continuing dividend payouts on the basis of the dividend rate based on share price on the day of GSM results in significantly negative cumulative abnormal returns for dividend rate decreases, while for dividend rate increases CARs are positive only when the significance level is chosen as 0.01 .

In the next step of the analysis, payout continuation is classified according to the dividend rate based on the share price at the beginning of the previous fiscal year, adjusted for WIG Index change, for which CARs are presented in table 7.

\section{TABLE 7. CARs for payout continuation- decrease and increase in the dividend rate based on share price at the beginning of previous fiscal year adjusted for WIG Index change vs. OLS assumptions}

\begin{tabular}{|c|c|c|c|}
\hline \multicolumn{4}{|c|}{ OLS assumptions fulfilled at the significance level } \\
\hline 0.1 & 0.05 & 0.01 & all events \\
\hline
\end{tabular}

\begin{tabular}{|c|c|c|c|c|c|c|c|c|}
\hline \multicolumn{9}{|c|}{$\begin{array}{l}\text { decrease in dividend rate based on share price at the beginning of previous fiscal year adjusted for WIG } \\
\text { Index change }\end{array}$} \\
\hline number of events & \multicolumn{2}{|c|}{51} & \multicolumn{2}{|c|}{80} & \multicolumn{2}{|c|}{121} & \multicolumn{2}{|c|}{269} \\
\hline CARs in days- $1,0,1$ & $0.01 \%$ & & $-0.58 \%$ & $* * *$ & $-0.35 \%$ & * & $-0.24 \%$ & \\
\hline CARs in days 0,1 & $-0.03 \%$ & & $-0.44 \%$ & $* *$ & $-0.12 \%$ & & $-0.11 \%$ & \\
\hline \multicolumn{9}{|c|}{$\begin{array}{l}\text { increase in dividend rate based on share price at the beginning of previous fiscal year adjusted for WIG } \\
\text { Index change }\end{array}$} \\
\hline number of events & \multicolumn{2}{|c|}{52} & \multicolumn{2}{|c|}{72} & \multicolumn{2}{|c|}{104} & \multicolumn{2}{|c|}{247} \\
\hline CARs in days- $1,0,1$ & $0.47 \%$ & $* *$ & $-0.51 \%$ & $* *$ & $-0.47 \%$ & ** & $-0.50 \%$ & \\
\hline CARs in days 0,1 & $0.35 \%$ & * & $-0.84 \%$ & $* * *$ & $-0.69 \%$ & $* * *$ & $-0.56 \%$ & \\
\hline
\end{tabular}

* significant at the 0.1 level; ${ }^{* *}$ significant at the 0.05 level; ${ }^{* *}$ significant at the 0.01 level.

S o u r c e : own elaboration on the basis of SAS System outcome. 
CARs for the decrease in the dividend rate are negative in 7 out of 8 cases presented in table 7, while for an increase they are positive in 2 out of 8 cases.

Cumulative abnormal returns are significantly different from zero for decreases in the dividend rate if OLS assumptions are fulfilled at the 0.05 level. In such a case, 3 -days CARs equal $-0.58 \%$, while 2 -days CARs amount to $-0.44 \%$. As with the dividend rate calculated with the methodology presented in table 6 , in this case there are also no events of dividend rate equal to the one observed for the previous payout. When it comes to increases in the dividend rate, CARs are positive and significant if the 0.1 level is chosen. However, when the significance level is changed to 0.05 , the CARs turn negative, which indicates a limited conclusiveness of the measure of dividend change used in table 7.

In the table 8 CARs for payout continuation classified by dividend rate based on share price at the end of fiscal year are presented.

TABLE 8. CARs for payout continuation- decrease and increase in the dividend rate based on share price at the end of fiscal year vs. OLS assumptions

\begin{tabular}{|c|c|c|c|c|c|c|c|c|}
\hline & & & assumptic & s fulf & at the sig & ificar & evel & \\
\hline & 0 & & 0. & & 0 . & & all e & nts \\
\hline decrease in dividend & ised on sh & re pr & the end & fisca & & & & \\
\hline number of events & 6 & & 8 & & & & 2 & \\
\hline CARs in days $-1,0,1$ & $-0.08 \%$ & & $-1.24 \%$ & $* * *$ & $-1.07 \%$ & $* * *$ & $-0.75 \%$ & ** \\
\hline CARs in days 0,1 & $-0.15 \%$ & & $-1.17 \%$ & $* * *$ & $-0.90 \%$ & $* * *$ & $-0.59 \%$ & $* *$ \\
\hline increase in dividend 1 & sed on sh & re pri & the end & fisca & & & & \\
\hline number of events & 4 & & 6 & & & & 2 & \\
\hline CARs in days- $1,0,1$ & $0.70 \%$ & $* * *$ & $0.37 \%$ & * & $0.43 \%$ & ** & $0.06 \%$ & \\
\hline CARs in days 0,1 & $0.59 \%$ & $* * *$ & $0.08 \%$ & & $0.27 \%$ & & $-0.04 \%$ & \\
\hline
\end{tabular}

${ }^{*}$ significant at the 0.1 level; ${ }^{* *}$ significant at the 0.05 level; ${ }^{* * *}$ significant at the 0.01 level.

S o u r c e: own elaboration on the basis of SAS System outcome.

CARs for a decrease in the dividend rate are negative in 8 out of 8 cases defined in the table above, while for an increase they are positive in 7 out of 8 cases.

Decreases in dividend rates calculated on the basis of share price at the end of the fiscal year were significant when OLS assumptions are fulfilled at significance levels of 0.05 or 0.01 , as well as when assumptions are not controlled for. For increases in the analogous dividend rate, most CARs are positive, while they are significantly different from zero only when the market model specification is properly specified at a 0.1 significance level.

To conclude, when the direction of change in dividend payouts is assessed on the basis of the dividend rate with share price at the end of the fiscal year, a negative reaction by investors is observed for decreases in payments, and a positive reaction for increases. 
Another way to group the events of continuing dividend payouts is by e use of a dividend payout rate. The results of such a division are presented in table 9.

TABLE 9. CARs for payout continuation- decrease and increase in the dividend payout rate vs. OLS assumptions

\begin{tabular}{|c|c|c|c|c|c|c|}
\hline & \multicolumn{6}{|c|}{ OLS assumptions fulfilled at the significance level } \\
\hline & 0.1 & \multicolumn{2}{|c|}{0.05} & \multicolumn{2}{|c|}{0.01} & all events \\
\hline \multicolumn{7}{|c|}{ decrease in dividend payout rate } \\
\hline number of events & 53 & \multicolumn{2}{|c|}{81} & \multicolumn{2}{|c|}{122} & \multirow[t]{2}{*}{269} \\
\hline CARs in days- $1,0,1$ & $0.59 \% \quad * *$ & $-0.33 \%$ & * & $-0.21 \%$ & & \\
\hline CARs in days 0,1 & $0.30 \%$ & $-0.24 \%$ & & $-0.08 \%$ & & $-0.29 \%$ \\
\hline \multicolumn{7}{|c|}{ increase in dividend payout rate } \\
\hline number of events & 50 & \multicolumn{2}{|c|}{71} & \multicolumn{2}{|c|}{103} & 247 \\
\hline CARs in days- $1,0,1$ & $-0.13 \%$ & $-0.79 \%$ & $* * *$ & $-0.64 \%$ & & $-0.35 \%$ \\
\hline CARs in days 0,1 & $0.01 \%$ & $-1.07 \%$ & $* * *$ & $-0.75 \%$ & $* * *$ & $-0.36 \%$ \\
\hline
\end{tabular}

${ }^{*}$ significant at the 0.1 level; ${ }^{* *}$ significant at the 0.05 level; ${ }^{* * *}$ significant at the 0.01 level.

S o u r c e : own elaboration on the basis of SAS System outcome.

CARs for a decrease in the dividend payout rate are negative in 6 out of 8 cases defined in the table above., For an increase, they are positive in 1 out of 8 cases.

There is no consistent pattern across CARs for decreases and increases in the dividend payout rate. Significant CARs for decreases are observed only when OLS assumptions are fulfilled at a 0.1 level. However, these are also cases when CARs are positive, while other results are negative (though insignificantly different from zero). For increases in the dividend payout rate most CARs are negative, while those calculated on the basis of the 0.05 or 0.01 significance levels are significantly different from zero.

Taking the above into consideration, a positive reaction to decreases and a negative reaction to increases in dividend payout ratios is observed, which undermines the applicability of this measure as a criterion for assessing the direction of dividend payment.changes.

\section{Discussion of the Results}

The results presented in the previous section can be assessed on the basis of the presented hypotheses, as well as the chosen significance level appropriate for OLS assumptions verification if the market model is estimated. Moreover, the most suitable measure of dividend change can be chosen. 
Without verification of the OLS assumptions, CARs for 2-days and 3-days event windows are insignificant, with two exceptions. The first is payout resumption, which yields significant negative returns - against the Main Hypothesis. The second is a decrease in dividend yield calculated on the basis of share price at the end of the fiscal year, which was negative and therefore in line with the Main Hypothesis. Taking the above into account, it shall be stated that OLS assumptions verification plays an important role in assessing the magnitude and direction of CARs generated by the market model, which in turn significantly affects the results of the study.

Choosing the lowest significance level of 0.01 results in significant CARs for 5 out of 14 events defined in the study. However, only in the case of a decrease in dividend yield calculated on the basis of share price at the end of fiscal year were investor reactions to the event in accordance with the hypotheses. Therefore, choosing 0.01 as the significance level for the study of investor reaction to the dividend announcements on the Polish market is not appropriate.

When it comes to significance levels of 0.05 and 0.1 , both point to the significance of CARs for most events. However, for irregular payouts and payout initiation, only 2-days CARs are significantly different from zero, with the former equal to $0.52 \%$ and the latter to $-0.42 \%$. As payout initiation should be viewed by investors as a positive signal about the prospects of the company, this incoherence with the Main Hypothesis could be seen as a reason for rejection of the 0.05 significance level.

The results of the analysis based on the most restrictive significance level are as follows. For irregular payouts, the 3-days and 2-days CARs amount to $1.73 \%$ and $1.54 \%$, respectively. Both results are in line with the Main Hypothesis and empirical studies results cited in the previous sections [e.g., Aharony, Swary, 1980]. Investor reaction to payout initiation is $2.44 \%$ within 3 days and $1.37 \%$ within 2 days. The direction of the reaction is in line with the Main Hypothesis, though in the case of a wider event window (only) the reaction to payout initiation is higher in magnitude than for irregular payouts, as observed by Kane et al. [1984]. When it comes to payout resumption, both 3-days and 2-days CARs are negative and amount to $-1,32 \%$ and $-1,63 \%$, respectively.

The event of payout resumption requires special attention. In the unrestricted sample of events, this group constitutes 52 of 444 analyzed events. It is defined as resuming payouts after one year of omission, and is incorporated into the study to widen the sample of regular dividend payouts. For this reason, this category is usually not distinguished in studies concerning American companies, which follow more stable dividend policies. It has to be underlined that in this study investor reaction to this event is significantly negative regardless of the significance level used for verification of the market model's assumptions. Therefore, the fact that the direction and magnitude of CARs for the 0.01 significance level is contrary to the prediction of the Main Hypothesis should not be regarded as a reason to opt for a preponderance of result for a different significance level. 
As previously stated, this study may also be used as a guideline for selecting a measure of future changes in dividend value from the point of view of investors. Five measures of dividend value are used: (1) the absolute value of dividend per share; (2) the dividend yield on the basis of share price measured at the end of the fiscal year; (3) the dividend yield on the basis of share price measured at the beginning of the fiscal year adjusted for the market index change; (4) the dividend yield on the basis of share price measured on the day of the GSM; and (5) the dividend payout yield.

Analysis of the CARs for changes in the absolute value of the dividend payout shows that a decrease in payouts results in a positive reaction, while no change and increase result in a negative reaction. These results contradict the Main Hypothesis, suggesting that other measures might be more appropriate for the research in question.

When it comes to changes in dividend yield based on share price measured at the end of the fiscal year, a decrease generates negative investor reaction of $-0,56 \%$ and $-0,48 \%$ for 3 -days and 2-days event window, respectively. The direction of change is in line with the Main Hypothesis, and the magnitude of positive investor reaction to payout increase is lower than to payout initiation, which supports Hypothesis 2. These results also confirm findings of previous research, like Denis et al. [1994]. Therefore, the measure of dividend payout change in question is appropriate for assessing the investor reaction.

Moving on to the dividend yield calculated on the basis of share price measured at the beginning of the fiscal year and adjusted for the market index change - only increases in this measure cause significant investor reaction of $0.47 \%$ for 3 -days event window and of $0.35 \%$ for the 2 -days event window. Although the direction and magnitude of this reaction is in line with the Main Hypothesis and Hypothesis 2, the lack of significance for decreases in dividend payouts suggests that application of this measure by investors is limited.

Taking into consideration decreases in dividend yield calculated on the basis of share price at the end of fiscal year, investor reaction to the event is insignificantly different from zero. For increases, the reaction is positive and amounts to $0.70 \%$ and $0.59 \%$ for days -1 , 0,1 and days 0,1 , respectively. Application of this measure is therefore limited.

The last measure among those analysed is the dividend payout rate. Only 3-days investor reaction to decreases in the dividend payout rate is significantly different from zero and amounts to $0.59 \%$. This not only contradicts the Main Hypothesis, but also suggests a limited significance of the results, which shall be interpreted as an argument against the applicability of this measure.

To conclude, the Main Hypothesis and Hypotheses 1 and 2 presented in this study are largely confirmed by the data. The 3 -days (2-days) reaction to payout initiation and irregular payouts are positive, and amount to $2.44 \%$ (1.37\%) and $1.73 \%$ (1.54\%), respectively. Positive price changes to payout initiation are also noticed by Czerwonka [2010]. The results in case of payout initiation are lower than observed by studies for the American market, e.g., Asquith and Mullins [1983] (+3,7\%). Both the direction of the reaction to payout initiation and the higher magnitude of that reaction as compared to irregular 
payouts, are in line with Hypothesis 1 . However, contrary to Hypothesis 1, investor reaction to resuming dividend payouts was negative.

As far as investor reactions to changes in dividends are concerned, dividend yield calculated on the basis of the share price on the day of the GSM was chosen as the most appropriate measure. Decrease dividend payout induced a negative reaction of $-0.56 \%$ for 3-day and $-0.38 \%$ for 2-day event windows. For payout increases, CARs for the same periods are, respectively, $0.82 \%$ and $0.62 \%$. In comparison to the results of previous studies, the reaction for Polish market is much weaker. For example, Denis et al. [1994] report a $1.25 \%$ reaction for payout increases and a $-5.27 \%$ reaction for payout decreases, while Aharony and Swary [1980] observe the average price changes of $0.93 \%$ and $-3.29 \%$, respectively, for payout increases and decreases. Gurgul and Majdosz [2005] and Perepeczo [2013] also confirm a positive reaction to dividend announcements for companies listed on WSE. Our findings are, however, against the view of Słoński and Zawadzki [2012] that the reaction to changes in dividend payout is not significantly different from zero. Those findings support the Main Hypothesis and Hypothesis 2 concerning both the direction and magnitude of positive investor reaction to dividend increase, which was weaker than in case of payout initiation. Since no instance of unchanged dividend yield are identified, Hypothesis 3 is not supported by the results.

\section{Conclusion}

This study analyzed investor reaction to the final value of dividend payouts for companies listed on the WSE. As the signalling hypothesis and agency cost hypothesis stipulate, initiations, irregular payouts, resuming and increasing dividend payouts should result in positive investor reaction, while a decrease in payout should lead to a negative reaction.

A significant positive investor reaction to irregular payouts and payout initiation is identified, while the reaction to irregular payouts was weaker than to payout initiation. Payout resumption resulted in negative investor reaction, which may stem from the definition of the event suggested. For payout continuation, the dividend yield calculated on the basis of share price on the day of GSM was the most appropriate measure of change in payout. The decrease in dividend payout caused a negative reaction, while an increase in dividend payout caused a positive reaction. There are no cases of unchanged dividend yield.

Moreover, due to comparison of the results with different significance levels (on the basis of which assumptions of OLS method for estimating market model are assessed), the 0.01 level was chosen as the most conclusive and most supportive for the hypotheses.

The magnitude of the reactions observed was significantly lower than in studies of American companies - 3-days positive reaction to payout initiation of $2.44 \%$ was observed 
in this study, in comparison with 3.7\% CARs in the study of Asquith and Mullins [1980]. The reaction to dividend changes is also weaker - in this study it is $-0.56 \%$ to decreases and $0,82 \%$ to increases, while Denis et al. [1994] report reaction of $-5.71 \%$ and $1.25 \%$, respectively.

Taking into consideration practical implication of the research, the low economic significance of the results, in comparison to previous research, suggests that the possibility of taking advantage of dividend announcements by traders and investors is limited. Although significant investor reaction to payout initiation and changes in payout was observed, there is little possibility of building a successful investment strategy based on price changes around the date of final dividend announcement made at General Shareholders' Meeting.

From the traders and investors' perspectives, it is desirable to examine the drivers of investor reaction to changes in dividend policies for companies from various industries and for companies at different life cycle stages. It is also possible to study factors concerning the financial performance of companies, which influence the direction and magnitude of investor reaction. On the basis of such results, it may be possible to determine which companies are most influenced by price changes around dividend announcement dates.

Further research may also focus on comparing investor reaction in other stock exchanges to changes in dividend payout. Groups of similar countries, like those of Central and Eastern Europe, or between developed and developing stock exchanges, would seem to offer particularly interesting targets.. Another interesting study would be to replicate this analysis for companies listed on stock exchanges operating in market-based and bank-based economies.

\section{Notes}

1 Although the definition of irregular payouts is based on information unavailable at the moment of dividend payout, it is assumed that managers' intention to regularly pay dividends (or not) is communicated to both analysts and investors.

2 Formulas are presented as in Gurgul [2012, p. 51].

\section{References}

Aharony, J., Swary, I. (1980), Quarterly Dividend and Earnings Announcements and Stockholders' Returns: An Empirical Analysis, The Journal of Finance, Vol. 35, No. 1, pp. 1-12. 
Allen, F., Bernardo, A.F., Welch, I. (2000), A Theory of Dividends Based on Tax Clienteles, The Journal of Finance, Vol. 55, No. 6, pp. 2499-2536.

Amihud, Y., Li, K. (2006), The Declining Content of Dividend Announcements and the Effects of Institutional Holdings, The Journal of Financial and Quantitative Analysis, Vol. 41, No. 3, pp. 637-660.

Asquith, P., Mullins, D.W. (1983), The Impact of Initiating Dividend Payments on Shareholders' Wealth, The Journal of Business, Vol. 56, No. 1, pp. 77-96.

Baker, M., Wurgler, J. (2004), A Catering Theory of Dividends, The Journal of Finance, Vol. 59, No. 3, pp. 1125-1165.

Bernartzi, S., Michaely, R., Thaler, R. (1997), Do Changes in Dividends Signal the Future or the Past?, The Journal of Finance, Vol. 52, No.3, Proceedings of Fifty-Seventh Annual Meeting, American Finance Association, New Orleans, Louisiana, January 4-6 1997, pp. 1007-1034.

Bhattacharya, S. (1979), Imperfect information, dividend policy, and "the bird in the hand" fallacy, pp. 259-270.

Brav, A., Graham, J.R., Harvey, C.R., Michaely, R. (2003), Payout Policy in the 21st Century, NBER Working Paper, No. 9657, pp. 1-37.

Brennan, M.J., Thakor, A.V. (1990), Shareholder Preferences and Dividend Policy, The Journal of Finance, Vol. 45, No. 4, pp. 993-1018.

Campbell, J.Y., Lo, A.W., MacKinlay, A.C. (1997), The Econometrics of Financial Markets, Princeton University Press. Capstaff, J., Klaeboe, A., Marshall, A.P. (2004), Share Price Reaction to Dividend Announcements: Empirical Evidence of the Signaling Model from the Oslo Stock Exchange, Multinational Finance Journal, 8 (1/2), pp. 115-139.

Chang, C., Kumar, P., Sivaramakrishnan, K. (2006), Dividend Changes, Cash Flow Predictability, and Signaling of Future Cash Flows, SSRN online library 881511.

Czerwonka, L. (2010), Wpływ zainicjowania wypłaty dywidendy na cenę akcji spółki, in: E. Urbańczyk (ed.) Uwarunkowania wzrostu wartości przedsiębiorstw w warunkach konkurencji, Zeszyty Naukowe Uniwersytetu Szczecińskiego, No. 634, pp. 67-85.

DeAngelo, H., DeAngelo, L., Skinner, D.J. (1992), Dividends and Losses, The Journal of Finance, Vol. 47, No. 5 , pp. 1837-1863.

Denis, D.J., Denis, D.K., Sarin, A. (1994), The Information Content of Dividend Changes: Cash Flow Signalling, Overinvestment, and Dividend Clienteles, The Journal of Financial and Quantitative Analysis, Vol. 29, No. 4, pp. 567-587.

Easterbrook, F.H. (1984), Two Agency-Cost Explanations of Dividends, The American Economic Review, Vol. 74, No. 4, pp. 650-659.

Elton, J., Gruber, M.J. (1970), Marginal Stockholder Tax Rates and the Clientele Effect, The Review of Economics and Statistics, Vol. 52, No. 1, pp. 68-74.

Fama, E.F., Fisher, L., Jensen, M.C., Roll, R. (1969), The adjustment of stock prices to new information, International Economic Review, Vol. 10., No. 1, pp. 1-21.

Fracassi, C. (2008), Stock Price Sensitivity to Dividend Changes, University of Texas Working Paper, pp. 1-39.

Ghosh, C., Woolridge, T.J.R. (1989), Stock-Market Reaction to Growth-Induced Dividend Cuts: Are Investors Myopic?, Managerial Decision Economics, Vol. 10, No. 1, pp. 25-35.

Goddard, J., McMillan, D.G., Wilson, J.O.S. (2006), Dividend Smoothing vs Dividend Signaling: Evidence from UK Firms, Managerial Finance, Vol. 32, No. 6, pp. 493-504.

Gordon, M.J. (1959), Dividends, Earnings, and Stock Prices, The Review of Economics and Statistics, Vol. 41, No. 2, Part 1, pp. 99-105.

Gordon, M.J. (1963), Optimal Investment and Financing Policy, The Journal of Finance, Vol. 18, No. 2, pp. 264-272.

Graham, J.R., Kumar, A. (2006), Do Dividend Clienteles Exist? Evidence on Dividend Preferences of Retail Investors, The Journal of Finance, Vol. 61, No. 3, pp. 1305-1336. 
Grullon, G., Michael, R., Benartzi, S., Thaler, R.H. (2005), Dividend Changes Do Not Signal Changes in Future Profitability, The Journal of Business, 78(5), pp. 1659-1682.

Gurgul, H. (2012), Analiza zdarzeń na rynkach akcji. Wplyw informacji na ceny papierów wartościowych, Wolters Kluwer.

Gurgul, H., Majdosz, P. (2005), Effect of Dividend and Repurchase Announcements on the Polish Stock Market, Badania Operacyjne i Decyzje, No 1, pp. 25-39.

Hawton, S., Hawton, S.D. (2006), The Corporate Response to the 2003 Dividend Tax Cut, Journal of Applied Finance, Vol.16, No.1, pp. 62-71.

Jagannathan, M., Stephens, C., Weisbach, M. (2000), Financial Flexibility and The Choice Between Dividends and Stock Repurchases, Journal of Financial Economics, Vol. 57, No. 3, pp. 355-384.

Jensen, G.R., Johnson, J.M. (1995), The Dynamics of Corporate Dividend Reductions, Financial Management, Vol. 24, No. 4, pp. 31-51.

Jensen, M.C. (1986), Agency Costs of Free Cash Flow, Corporate Finance and Takeovers, The American Economic Review, Vol. 76, No. 2, Papers and Proceedings of the Ninety-Eight Annual Meeting of the American Economic Association, pp. 323-329.

John, K., Williams, J. (1985), Dividends, Dilution, and Taxes: A Signalling Equilibrium, The Journal of Finance, Vol. 40, No. 4, pp. 1053-1070.

Jo, H., Pan, C. (2009), Why are firms with entrenched managers more likely to pay dividends?, Review of Accounting and Finance, Vol. 8, No. 1, pp. 87-11.

Kalay, A., Lemmon, M. (2008), Payout Policy, in: E. Eckbo (ed.), Handbook of Corporate Finance, Empirical Corporate Finance, Vol. 2, Elsevier.

Kane, A., Lee, Y.K., Marcus, A. (1984), Earnings and Dividend Announcement: Is There a Corroboration Effect?, The Journal of Finance, Vol. 39, No. 4, pp. 1091-1099.

La Porta, R., Lopez-de-Silianes, F., Shleifer, A., Vishny, R.W. (2000), Agency Problems and Dividend Policies around the World, The Journal of Finance, Vol. 55, No. 1, pp. 1-33.

Levinsohn, A. (2005), Divine Dividends, Strategic Finance, 86(11), pp. 59-60.

Lintner, J. (1956), Distribution of Incomes of Corporation among Dividends, Retained Earnings and Taxes, The American Economic Review, Vol. 46, No. 2, Papers and Proceedings of the Sixty-eighth Annual Meeting of the American Economic Association, pp. 97-113.

Lintner, J. (1962), Dividends, Earnings, Leverage, Stock Prices and the Supply of Capital to Corporations, The Review of Economics and Statistics, Vol. 44, No. 3, pp. 243-269.

Litzenberger, H., Ramaswamy, K. (1982), The Effect of Dividends on Common Stock Prices Tax Effects or Information Effects?, The Journal of Finance, Vol. 37, No. 2, Papers and Proceedings of the Fortieth Annual Meeting of the American Finance Association, Washington D.C., December 28-30, 1981, pp. 429-443.

Li, K., Zhao, sX. (2008), Asymmetric Information and Dividend Policy, Financial Management, 37 (4), pp. 673-694. Lucas, D.J., McDonald, R.L. (1998), Shareholder Heterogeneity, Adverse Selection and Payout Policy, The Journal of Finance and Quantitative Analysis, Vol. 33, No. 2, pp. 233-253.

Michaely, R., Thaler, R.H., Womack, K.L. (1995), Price Reactions to Dividend Initiations and Omissions: Overreaction or Drift?, The Journal of Finance, Vol. 50, No. 2, pp. 573-608.

Mikhail, B., Walther, B.R., Willis, R.H. (1999), Dividend Changes and Earnings Quality, Journal of Accounting, Auditing and Finance, Vol. 18, pp. 1-35.

Miller, M.H., Modigliani, F. (1961), Dividend Policy, Growth, and the Valuation of Shares, The Journal of Business, Vol. 34, No. 4, pp. 411-433. 
Nissim, D., Ziv, A. (2001), Dividend Changes and Future Profitability, The Journal of Finance, Vol. 56, No. 6, pp. 2111-2133.

Perepeczo, A. (2013), Reakcja akcjonariuszy na zmiany polityki dywidend - przegląd wyników badań, Zeszyty Naukowe Uniwersytetu Szczecińskiego, No. 761, pp. 251-261.

Pettit, R.R. (1972), Dividend Announcements, Security Performance, and Capital Market Efficiency, The Journal of Finance, Vol. 27, No. 5, pp. 993-1007.

Robin, J. (1998), Dividend Omissions: Rationale and Market Impact, American Business Review, Vol. 16, No. 2 , pp. 1-8.

Rozeff, M.S. (1982), Growth, Beta and Agency Costs as Determinants of Dividend Payout Policy, The Journal of Financial Research, Vol. V, No. 3, pp. 249-259.

Słoński, T., Zawadzki, B. (2012), Analiza reakcji inwestorów na zmianę wielkości wypłacanej dywidendy przez spółki notowane na GPW w Warszawie, Annales Universitatis Mariae Curie-Skłodowska. Section H. Oeconomia, Vol. 46/1 (XLVI), pp. 125-135.

Vieira, E.S., Raposo, C.C. (2007), Signalling with dividends? The signalling effects of dividend change announcements: new evidence from Europe. http://ssrn.com/abstract=955768

Woolridge, J.R. (1983), Dividend Changes and Securities Prices, The Journal of Finance, Vol. 38, No. 5, pp. 1607-1615. Yoon, S., Starks, L.T. (1995), Signaling, Investment Opportunities, and Dividend Announcements, The Review of Financial Studies, Vol. 8, No. 4, pp. 995-1018. 